\title{
Variation in the chemical composition and the nutritive quality of different field bean UK grown cultivar samples for broiler chicks
}

\author{
by Abdulla, J.M., Rose, S.P., Mackenzie, A. and \\ Pirgozliev, V.
}

Copyright, publisher and additional information: .This is the authors' accepted manuscript. The published version is available via Taylor \& Francis

Please refer to any applicable terms of use of the publisher

DOI link to the version of record on the publisher's site

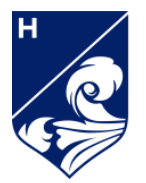

Harper Adams University

Abdulla, J.M., Rose, S.P., Mackenzie, A. and Pirgozliev, V. 2020. Variation in the chemical composition and the nutritive quality of different field bean UK grown cultivar samples for broiler chicks. British Poultry Science.

7 October 2020 
3

\section{Variation in the chemical composition and the nutritive quality of different field} bean UK grown cultivar samples for broiler chicks

Jalil Mahmwd Abdulla ${ }^{1,2}$, Stephen Paul Rose ${ }^{1}$, Alexander Mackay Mackenzie ${ }^{1}$, and Vasil Radoslavov Pirgozliev ${ }^{1}$

${ }^{1}$ National Institute of Poultry Husbandry, Harper Adams University, Newport, Shropshire, TF10 8NB, UK

${ }^{2}$ Department of Biology, Faculty of Science, Soran University, The Kurdistan Region of Iraq.

Corresponding author: V. Pirgozliev. E-mail: vpirgozliev@harper-adams.ac.uk $\mathrm{T}:+44(0) 1952820280 \mathrm{~F}:+44$ (0) 1952814783

Abstract 1. The chemical composition and physical characteristics of ten colour-flowered different UK grown field bean cultivar samples from the same harvest year were determined. Compositional variation existed between the beans.

2. Diets that included each bean sample at $200 \mathrm{~g} / \mathrm{kg}$ were used to compare broiler growth performance and determine $\mathrm{N}$-corrected apparent metabolizable energy (AMEn) and nutrient utilisation. The AMEn and nutrient retention coefficients for the bean samples were obtained via slope ratio method. The relationships were examined between these variables of nutritive value for broilers and the laboratory analysis on the bean samples.

3. Findings showed differences $(P<0.05)$ among the bean cultivar samples for feed conversion ratio, AMEn and dry matter retention (DMR) coefficients. Further analysis showed that feeding quality of different field bean cultivar samples measured as AMEn highly correlates to crude protein $(C P)(P<0.05)$ contents and the colour $(P<0.001)$ of the samples. Thus, beans with higher $\mathrm{CP}$ and pale colour have superior feeding value for broilers.

Key words: broilers, field beans, nutrient avalability, metabolisable energy, chemical composition 


\section{Introduction}

Soybeans, which are a common source of protein in poultry diets due to having a high level of protein and well balanced profile of amino acids, are an imported feed ingredient in the UK. From 2002-2018 the average total of imported soybeans (as whole seed) to the UK was about 791930 tonnes per year (Statista 2020). The price of soybean meal (SBM) is increasing continuously as a result of rising demand globally, particularly after prohibition of animal protein inclusion in poultry diet by the European Union (O'Neill et al. 2012). Additionally, large amount of the available SBM in the market is produced from genetically modified crops which worries consumers and is not suitable for organic production (Vicenti et al. 2009). Also, according to Gasparri et al. (2013), increasing global demand for SBM caused deforestation of millions of hectares in South America, especially over last half century, which have left a negative impact on Carbon Footprint and Global Environmental Changes. Furthermore, recently the European Union has stimulated animal producers to exploit locally grown legumes such as field beans in their diet formulations, aiming for ecological and financial benefits (Fru-Nji et al. 2007). Therefore, the search for locally grown alternative protein sources that can totally or at least partially replace SBM is necessary, thus, decreasing or ending the dependency of the UK poultry feed industry on imported SBM as a source of protein and avoiding or reducing the worries connected with SBM. High concentrations of proteins in field beans and similarity of their amino acids profile to that of soybeans, renders them to be considered as a desirable candidate to replace SBM, at least partially, in poultry diet formulations. Field beans could possibly be produced in greater amounts in the UK due to the suitability of the climate and the available cultivars. In the recent years, as a consequence of breeding and increased area where field beans are being planted in, the annual UK production of field beans has approximately 600000 tonnes (PGRO 2017), however, very little of it is employed in UK animal feed formulation and the 
rest is exported. Nowadays, the demand on producing field beans is increasing and this increase is expected to continue, thus they will be an available feedstuff at a high amount in the UK market.

It has been reported that field beans can be included at 20 to $30 \%$ in broiler diets without any adverse effect on performance (Farrell et al. 1999; Usayran et al. 2014; Abdulla et al. 2017). However, there is uncertainty about the chemical composition, which may vary between different cultivars, especially with regards to the type and amount of anti-nutrients that they may contain. This may also result in variation of their energy and nutrient availability for broilers.

Adequate and precise information on the chemical composition and nutritive value of different locally-grown field bean cultivars provides flexibility and constancy to the poultry feed industries, allowing them to include field beans in their diet formulations.

The main objectives of this experiment were: To examine the differences in metabolizable energy, and nutrient availability of ten UK grown field bean cultivar samples. To examine the relationship between chemical composition of the field bean sample to the bioavailable energy and nutrients. Differences in productive performance of broilers when fed these beans are reported and compared although the nutrient variation between the bean samples was not corrected in the diets.

\section{Material and methods}

\section{Field bean cultivar samples}

Ten colour-flowered different UK grown field bean cultivar samples, including three spring (Fuego, Fury and Maris Bead) and seven winter (Arthur, Buzz, Clipper, Divine, Honey, Sultan and Wizard) grown cultivars, from 2013 harvest year were obtained from the market (primarily from Askew \& Barrett (Pulses) Ltd, Wisbech, UK). The beans were grown at different locations and there was no information on agronomy or soil type available. All harvested field bean samples were stored at ambient air temperatures in a dry store and were used in broiler feeding experiment after approximately 6 months of their storage. 
Before the animal feeding experiment, the field bean samples were hammer-milled using a $4 \mathrm{~mm}$ screen and then mixed in a horizontal mixer with the other feed ingredients. Freshly milled field beans were used for analyses and in the feeding study to avoid spoilage.

\section{Proximate analysis and gross energy in field bean and excreta samples}

Dry matter was determined by drying samples at $105^{\circ} \mathrm{C}$ to constant weight (AOAC 1990; 925.10). Crude protein $(\mathrm{N} \times 6.25)$ concentration in the samples was determined by the dry combustion method, using a Leco (FP-528 N, Leco Corp., St. Joseph, MI). Oil (as ether extract) was extracted with diethyl ether by the extraction method (AOAC 2000), employing a Soxtec system (Foss UK Ltd). Gross energy of the samples was measured using a Parr adiabatic bomb calorimeter (Parr-6200 Calorimeter, Parr Instruments Company, Moline, IL, USA), and benzoic acid was used as the standard.

\section{Carbohydrate and mineral contents in field bean samples}

Total starch was determined by a modified version of Englyst et al. (2000), which involved initial heat dispersion together with heat stable amylase followed by treatment with alkali to disperse any retrograded type III resistant starch. Non-starch polysaccharides (NSP) content in field beans was determined by the method of Englyst et al. (1994). In brief, starch is completely dispersed, hydrolysed enzymatically, and the NSP is isolated by precipitation in $80 \%$ ethanol, hydrolysed by sulphuric acid and the released sugars are measured by gas chromatography.

The mineral contents of the field bean samples were determined according to the procedure described by Tanner et al. (2002), employing inductively coupled plasma emission spectrometry (Optima 4300 DV Dual View ICP-OE spectrometer, Perkin Elmer, Beaconsfield, UK).

\section{Phenols, tannins, phytate and trypsin inhibitors}

Phenolic compounds, including total phenols, non-tannin phenols, and total tannins (as tannic acid equivalent), in the representative samples of the field beans were measured 
117 chemically as described by Makkar et al. (1993). In brief, phenolic compounds from samples

118 were extracted with $70 \%$ aqueous acetone and measured using spectrophotometer. The

119 tannin extract containing tubes were kept on ice until all phenolic analyses were completed

120 during the same day. The phytate and phytate phosphorus contents in the field bean

121 samples were determined by HPLC as described by Kwanyuen and Burton (2005). Trypsin

122 inhibitor content in the field beans was measured by applying the assay proposed by Smith 123 et al. (1980).

\section{Grain quality and viscosity of the experimental bean samples}

126 The colour score of whole fine milled bean of each cultivar sample was read in triplicate,

127 after submerging the instrument into the samples in petri dishes, employing an $L^{*} a^{*} b^{*}$ 128 colour space (Konica Minolta, Chroma Meter CR-400, Essex, UK). The instrument was 129 calibrated against a standard white-coloured reference tile and cleaned between taking measurements of different samples. The $L^{*}$ indicates lightness, $0-100$ representing dark to light. The $a^{*}$ value gives the degree of the red-green colour, with a higher positive $a^{*}$ value indicates more red. The $b^{*}$ value indicates the degree of the yellow-blue colour, with a higher positive $b^{*}$ value indicating more yellow.

134 For the determination of hull to kennel ratio, 100 grams of clean representative grain 135 sample of each field bean variety was taken, seed coats were completely separated from cotyledons with the aid of pliers, and the weights of each of cotyledons and seed coats alone were measured. The weight of 1000 grains, the water holding capacity and the water extracted viscosity of the field beans were determined as previously described by Pirgozliev et al. (2003). Water extracted viscosity was measured with a rotating cone and cup

140 viscometer (model DV-II + LV Brookfield, Stroughton, MA, USA). 


\section{Diet formulation}

Birds were fed one of twelve mash diets. A wheat-soybean based balancer diet (control diet) was formulated that had major ingredients of $533.2 \mathrm{~g} / \mathrm{kg}$ wheat, $150.0 \mathrm{~g} / \mathrm{kg} \mathrm{SBM}, 175.0$ $\mathrm{g} / \mathrm{kg}$ full fat soya, $37.4 \mathrm{~g} / \mathrm{kg}$ maize gluten meal, and $50 \mathrm{~g} / \mathrm{kg}$ vegetable oil, and contained $231 \mathrm{~g} / \mathrm{kg} \mathrm{CP}$ and $13.71 \mathrm{MJ} / \mathrm{kg}$ metabolisable energy (ME) (Table 1). The balancer diet had higher ME content than breeder's recommendation (Aviagen Ltd., Edinburgh, UK) to allow the $\mathrm{ME}$ of the field bean containing diets to be close to the requirements. The balancer diet also contained $5 \mathrm{~g} / \mathrm{kg}$ of $\mathrm{TiO}_{2}$ as an indigestible marker, although this was not used for further analysis. Ten diets were then produced including $200 \mathrm{~g} / \mathrm{kg}$ of one of the ten different field bean cultivars and $800 \mathrm{~g} / \mathrm{kg}$ of the balancer feed. To allow testing of whether there was a linear relationship between the level of substitution of an individual field bean sample and the determined ME or nutrient availability of the diet, another diet was formulated that contained $100 \mathrm{~g} / \mathrm{kg}$ of the Honey field bean sample and $900 \mathrm{~g} / \mathrm{kg}$ of the balancer feed (so giving three diets with three different inclusion rates of the cultivar Honey). Twelve experimental diets were compared in total. Freshly milled field beans were used in the formulation of the diets and were fed as mash. All diets approximately met or exceeded the dietary specifications for Ross 308 broilers (Aviagen Ltd., Edinburgh, UK). Diets did not contain any coccidiostat, antimicrobial growth promoters, prophylactic or other similar additives.

\section{Husbandry and sample collection}

The experiment was conducted at the National Institute of Poultry Husbandry and approved by the Research Ethics Committee of Harper Adams University, UK. Approximately fivehundred day-old male Ross 308 broiler chicks were obtained from a commercial hatchery (Cyril Bason, Shropshire, UK). All chicks were placed in a single rear pen at $33^{\circ} \mathrm{C}$ and fed a proprietary broiler starter feed ad libitum over seven days. On the first day of the experiment ( $8 \mathrm{~d}$ of age), all chicks were individually weighed and unusual birds were discarded, leaving 480 birds. Those birds were then randomly allocated into 96 raised-floor pens $\left(0.36 \mathrm{~m}^{2}\right.$ floor area; five birds in each pen). The pens were arranged in one tier level 
173 within a controlled environment room, and each pen was equipped with a plastic feeder and 174 drinker. The floor of the pens was covered with wood shavings. Each of the twelve 175 experimental diets was fed to 8 pens following randomisation. Feed and water were provided ad libitum throughout the experimental period.

177 The temperature was gradually reduced daily until room temperature reached $23^{\circ} \mathrm{C}$ 178 when birds were $21 \mathrm{~d}$ old. A standard lighting programme for broilers was used, decreasing 179 from 23:1 (hours light: dark) from zero day old to $18 \mathrm{~h}: 6 \mathrm{~h}$ at 7 days of age, which was 180 maintained until the end of the study.

181 The experiment ended when the birds were $21 \mathrm{~d}$ of age. The birds were group-weighed on a per pen basis at the beginning ( $8 \mathrm{~d}$ old) and at the end of the study ( 21 day old), and 183 the average daily feed intake (FI) and bird weight gain (WG), and feed conversion ratio 184 (FCR) were determined over this time.

185 At the beginning of $18 \mathrm{~d}$, the solid floor of each pen was replaced with a wire mesh and 186 all excreta were quantitatively collected daily in a plastic tray over the four final days of the experiment, from 18 to $21 \mathrm{~d}$ age. Feed intakes were also measured for the same period.

188 The freshly collected total excreta output of each pen was immediately dried in a forced draft oven at $60^{\circ} \mathrm{C}$ to a constant weight and then left at room temperature for three days 190 followed by weighing.

\section{Determination of dietary metabolisable energy and nutrient retention coefficients}

The dried excreta, as well as representative balancer diet samples were ground to pass through $0.8 \mathrm{~mm}$ screen. The dry matter, gross energy, nitrogen and fat of each dried excreta and the balancer diet samples were determined in duplicate as described for the field bean samples earlier.

The N-corrected apparent metabolisable energy (AMEn) of the diets was determined using total collection technique as described by Hill and Anderson (1958). The coefficients of total tract fat retention (FR), nitrogen retention (NR) and dry matter retention (DMR) were determined as the difference between intake and excretion of the nutrient divided by its respective intake. 


\section{Statistical analysis}

204 The observational unit was the raised-floor pen with 5 birds. Statistical analyses were performed using the Genstat $18^{\text {th }}$ statistical software package (Genstat 17 release 3.22 for

206 Windows; IACR, Rothamstead, Hertfordshire, UK). The AMEn and the nutrient utilisation 207 coefficients of the experimental field bean samples were statistically compared using a randomized block analysis of variance. The position of pens within the room was used as the blocking factor. Tukey's range test was used to determine significant differences between field bean treatment groups.

211 Regression analysis was used in order to test linear response of AMEn and nutrient 212 utilisation to inclusion rates of bean samples. Then the AMEn and values of the nutrient 213 retention coefficients were obtained using the slope ratio method (Finney 1978).

214 The coefficients of correlation between all studied variables were also obtained.

\section{Results}

Proximate analysis and gross energy in field beans

220 There were differences in the chemical composition and GE among the studied field bean 221 cultivar samples (Table 2). The overall means of protein, ash, oil and GE of the beans were $282.4,35.9,10.8 \mathrm{~g} / \mathrm{kg} \mathrm{DM}$ and $18.46 \mathrm{MJ} / \mathrm{kg} \mathrm{DM}$, respectively.

223 Generally, the GE contents were quite similar between different cultivars, ranged from 22418.27 (Bazz and Sultan) to $18.60 \mathrm{MJ} / \mathrm{kg} \mathrm{DM}$ (Divine), indicating a difference of $0.33 \mathrm{MJ}$, and with a coefficient of variation $(\mathrm{CV}=0.7 \%)$. Ether extract was the most variable nutrient (CV

$226=10.1 \%$ ), although mean levels were low. Crude protein concentration had intermediate 227 variability $(\mathrm{CV}=6.5 \%)$, and the difference between cultivar samples was approximately 60 $228 \mathrm{~g} / \mathrm{kg}$ DM. 
231 The carbohydrate profiles of the field bean samples are displayed in Table 3. The major 232 component of field bean carbohydrates was starch and its average content in the studied 233 cultivars was $456 \mathrm{~g} / \mathrm{kg} \mathrm{DM}(\mathrm{CV}=7.4 \%)$. There was a mean of $182 \mathrm{~g} / \mathrm{kg}$ of total NSP in the bean samples $(\mathrm{CV}=15.8 \%)$ and $72 \%$ was insoluble NSP.

The predominant constituent sugars of NSPs were glucose, galacturonic acid, arabinose and xylose, respectively. Whereas, the levels of total galactose and mannose were low, and both rhamnose and fucose were scarce.

238 Soluble galacturonic acid ranged from 10.1 to 20.3 and glucose from 1.5 to $25 \mathrm{~g} / \mathrm{kg} \mathrm{DM}$ 239 in Maris Bead and Clipper, correspondingly, and soluble arabinose scored 7.6 (MB) to 17.6 $240 \mathrm{~g} / \mathrm{kg}$ DM (Honey). The concentrations of 62.8 to 125.7 of insoluble glucose, and 7.1 to 14.1 $241 \mathrm{~g} / \mathrm{kg}$ DM of insoluble galacturonic acid were found in Honey and Clipper, respectively.

242 The mineral contents of the studied field bean cultivars are summarized in Table 4. The 243 concentrations of calcium, magnesium, potassium, sodium, sulphur and boron were similar 244 among the cultivars. Phosphorus concentration varied between 4.33 to $6.87 \mathrm{~g} / \mathrm{kg}$ DM for 245 Arthur and Wizard, respectively. Copper content was variable between samples with a CV $246=26.3 \%$.

Phenols, tannins, phytate and trypsin inhibitors

Total phenols, tannins, non-tannin phenols, condensed tannins, phytate and trypsin inhibitor contents of the studied field bean cultivars are presented in table 5. The majority of phenolic compounds in the field beans were tannins and non-tannin phenols were low. The mean total tannin concentration was $5.11 \mathrm{mg} / \mathrm{g}$ with a CV of $34.3 \%$. Non-tannin phenol contents, as tannic acid equivalent, were $2.02 \mathrm{mg} / \mathrm{g}(\mathrm{CV}=35.0 \%)$. The mean of condensed tannin 254 (CT) contents, as leucocyanidin equivalents, in bean cultivars was $5.04 \mathrm{mg} / \mathrm{g}$ DM (CV = $25530.9 \%)$. The overall mean of phytate was $14.5 \mathrm{mg} / \mathrm{g}(\mathrm{CV}=24.6 \%)$, although for trypsin 256 inhibitors it was $3.5 \mathrm{mg} / \mathrm{g}(\mathrm{CV}=19.2 \%)$. 
259 Color score of bean flour is illustrated in table 6 . The range of lightness scores was from 88 to $95(\mathrm{CV}=2.4 \%)$. The $\mathrm{a}^{*}$ (redness-greenness degree) of bean flour varied from 0.99 to $1.44(\mathrm{CV}=11.7 \%)$. The overall mean for $\mathrm{b}^{*}$ (yellowness-blueness degree) of bean flour was $18(\mathrm{CV} \%=10.6)$.

Thousand-grain weight (TGW), water holding capacity (WHC), viscosity, cotyledon ratio and seed-coat ratio of the characterized field bean samples are also presented in table 6 . The mean of WHC of the field bean samples was $954 \mathrm{~g} / \mathrm{kg} \mathrm{DM} \mathrm{(CV} \mathrm{=} \mathrm{4.5 \% ).} \mathrm{The} \mathrm{average}$ of seed-coat proportion was $136 \mathrm{~g} / \mathrm{kg}(\mathrm{CV}=10.1 \%)$. Viscosity $(\mathrm{cP})$ of field beans was variable $(\mathrm{CV}=25.8 \%)$ with a range from 2.07 to $5.01 \mathrm{cP}$.

\section{Analysis on data from the animal phase}

270 The data from basal diet and the diet contained 10\% Honey field bean cultivar were used

271 for testing linearity only and was not presented in tables with data on beans only.

\section{Linearity}

274 There was a linear change in AMEn and DMR $(P<0.001)$ to the three different inclusion rates of Honey bean sample, thus demonstrating the validity of the slope-ratio method that was employed for determination of these variables in the field bean cultivar samples (Table 277 7).

\section{Broiler growth performance, available energy and nutrient utilisation of field beans}

There were no mortalities and all birds survived the experiment. The variation in daily FI, WG and FCR were in the expected range for broiler chickens reared from 7 to $21 \mathrm{~d}$ old in group pens of 5 birds (coefficient of variation ( $C V=5.3 \%, 6.0 \%$, and $2.5 \%$, respectively)

283 (Table 8). Compared to breeder's recommendation, daily FI was approximately $10 \mathrm{~g} /$ day lower probably due to the feed being in a meal form rather than pelleted. There were no significant differences $(P>0.05)$ in daily $\mathrm{FI}$ and WG. The overall FCR was in the expected range (Aviagen Ltd., Edinburgh, UK), as Divine gave a better $(P<0.001)$ FCR comparing to Buzz and Sultan, but did not differ $(P>0.05)$ from the rest. 
The results on the AMEn, CPR, FD and DMR coefficients of the field bean cultivar samples are presented on table 8. The AMEn ranged from 7.78 to $9.96 \mathrm{MJ} / \mathrm{kg} \mathrm{DM}$. The large ranged AMEn was due to the AMEn of one sample (Sultan) that was highly significantly lower $(P<0.001)$ than that of Divine, Fury, Fuego and Wizard, field bean cultivar samples. There were no significant $(P>0.05)$ differences between the other nine samples except that the AMEn of Buzz was highly significantly $(P<0.001)$ lower than that of Divine. There were no differences $(P>0.05)$ in NR and FR between the studied field bean cultivar samples.

\section{Relationship between chemical composition and physical characteristics of the} beans, beans available energy and nutrients, and chicken growth performance

Selected correlation coefficients obtained using all the data from the laboratory analysis and broiler experiments are presented in Table 9. The CP content was correlated positively $(P$ $<0.05)$ to determined AMEn and lightness-darkness degree. Similarly, the lightnessdarkness degree correlated positively $(P<0.001)$ to AMEn. There was a positive correlation $(P<0.001)$ between tannins content and yellowness-blueness degree.

\section{Discussion}

The purpose of this experiment was to determine the range of variation in energy and nutrient availability of ten UK grown field bean cultivar samples. In addition, it aimed to determine how their AMEn and nutrient utilization relates to their chemical and physical composition.

\section{Broiler performance}

The overall final body weight of the birds in all dietary treatments was in the expected range for Ross 308 broilers fed on mash diets (Pirgozliev et al. 2015; Abdulla et al. 2016 a, b) as FCR was similar to breeder's recommendations (Aviagen Ltd, Edinburgh). The differences in birds feed intake and growth were not statistically significant in this study, although there were some differences in FCR. This is in agreement with previous reports (Metayer et al. 
317 2003; Nalle et al. 2010a) when similar amount of dietary beans were fed to broilers for the

318 same feeding period. The lack of response of growth performance variables to dietary bean 319 cultivars reported by Usayran et al. (2014) may be due to the relatively short feeding period 320 (7 days only) and the use of tannin-free bean cultivars.

322 Energy availability of field beans for broilers

323 The overall determined AMEn value of the field beans was $9.22 \mathrm{MJ} / \mathrm{kg} \mathrm{DM}$, which is similar 324 to other reports with broilers (Nalle et al. 2010a, b; Lacassagne et al. 1991). The AMEn for 325 Sultan was numerically the lowest and significantly lower than that of Divine, Fury, Fuego and Wizard field bean cultivar samples. Sultan had one of the lowest seed sizes, the lowest proportion of cotyledon, and one the greatest proportions of seed-coat in its overall seed 328 composition. However, this did not result in a lower starch content or increased NSP content 329 compared to the other samples, although protein content was low. The AMEn of Sultan was $3301.6 \mathrm{MJ} / \mathrm{kg}$ lower than the mean of the other nine samples. The reduced protein content in 331 Sultan would only account for approximately half of this lowered AMEn. Sultan had the highest polyphenol and tannin contents of the ten samples. However, it is well documented that tannin content in field beans reduces their AMEn (Brufau et al. 1998; Lacassagne et al. 334 1988; Vilariño et al. 2009). Similarly, tannin content in beans was associated with reduced 335 dietary nitrogen retention (Marquardt and Ward 1979) and ileal amino acid digestibility (Ortiz 336 et al. 1993; Woyengo and Nyachoti 2012). In agreement with this report, Igbasan et al. 337 (1997) observed higher metabolizable energy contents in light (both yellow and green) pea 338 cultivars than those in dark (brown) ones when fed mature cockerels. It has been found that pale legume seeds have higher nutritive value than dark seeds. It has been noted that seedcoat colour has some connection with the level of one or more anti-nutrients in field beans.

341 In comparison with light coloured cultivar samples, slightly high amounts of phenols and 342 tannins (Helsper et al. 1993; Oomah et al. 2011), phytate (Rubio et al. 1992) and fibres, but 343 lower CP (Helsper et al. 1993; Duc et al. 1995) in dark coloured field beans has been 344 reported. It has been known these compounds decrease the feeding quality of feedstuffs 
345 for monogastric animals. In addition, Brufau et al. (1998) and Vilariño et al. (2009) reported

346 negative relation between tannin level and metabolizable energy contents in field beans.

347 The results of this experiment have indicated that these ten field bean cultivar samples had 348 different energy and nutrient availabilities. The commercial poultry industry requires broiler 349 diets to have high energy densities. Nutritionists will only be able to incorporate significant 350 amounts of field beans in poultry diets if the beans have a high metabolizable energy. It is 351 crucial that they are able to identify and only use samples with high metabolizable energy. 352 The results of the present experiment have shown that there is an excessively large range 353 in the determined metabolizable energy of ten different UK field bean samples. There is an 354 indication from these samples that the metabolizable energy of different field bean cultivar 355 samples can be predicted by their crude protein contents and colour $\left(L^{*}\right)$. These 356 characteristics of field bean samples could be used as a rapid test of their nutritive quality. 357 However, the significant relationships were predominantly influenced by the physical 358 characteristics of only one field bean sample (Sultan). The relationship was not significant 359 in the remaining nine samples, even though the large range in metabolsibale energy still 360 remained. This information may be a guide to plant breeders who may be able to incorporate 361 it in the development of new field bean cultivars.

\section{Acknowledgements}

365 We thank Richard James and Rose Crocker for their technical support. We also thank 366 Askew \& Barrett (Pulses) Ltd. which donated the field bean samples for this study.

368 Disclosure statement

369 No potential conflict of interest was reported by the authors.

\section{$371 \quad$ Funding}

372 This experiment is a part of a PhD project funded by the Ministry of Higher Education and 373 Scientific Research - Kurdistan Regional Government - Iraq 


\section{References}

376

377

378

379

380

381

382

383

384

ABDULLA, J. M., S. P. ROSE, A. M. MACKENZIE, AND V. R. PIRGOZLIEV. 2017. "Feeding Value of Field Beans (Vicia Faba L. Var. Minor) with and without Enzyme Containing Tannase, Pectinase and Xylanase Activities for Broilers." Archives of Animal Nutrition 71 (2): 150-164. doi:10.1080/1745039x.2017.1283823.

ABDULLA, J. M., S. P. ROSE, A. M. MACKENZIE, S. G. IVANOVA, G. P. STAYKOVA, AND V. R. PIRGOZLIEV. 2016b. "Nutritional Value of Raw and Micronised Field Beans (Vicia Faba L. Var. Minor) with and without Enzyme Supplementation Containing Tannase for Growing Chickens." Archives of Animal Nutrition 70 (5): 350-363. doi:10.1080/1745039x.2016.1214344.

ABDULLA, J., S. P. ROSE, A. M. MACKENZIE, W. MIRZA, AND V. PIRGOZLIEV. 2016a. "Exogenous Tannase Improves Feeding Value of Diet Containing Field Beans (Vicia Faba) When Fed to Broilers." British Poultry Science 57 (2): 246-250. doi:10.1080/00071668.2016.1143551.

AOAC. 1990. Official Methods of Analysis. 17th ed. Gaithersburg, USA: Association of Official Analytical Chemists.

AOAC. 2000. Official Methods of Analysis. 17th ed. Gaithersburg, USA: Association of Official Analytical Chemists.

BRUFAU, J., D. BOROS, AND R. R. MARQUARDT. 1998. “Influence of Growing Season, Tannin Content and Autoclave Treatment on the Nutritive Value of Near-Isogenic Lines of Faba Beans (Vicia Faba L.) When Fed to Leghorn Chicks." British Poultry Science 39 (1): 97-105. doi:10.1080/00071669889457.

DUC, G., N. BRUN, R. MERGHEM, AND M. JAY. 1995. "Genetic Variation in TanninRelated Characters of Faba-Bean Seeds (Vicia Faba L.) and Their Relationship to SeedCoat Colour." Plant Breeding 114 (3): 272-274. doi:10.1111/j.1439-0523.1995.tb00812.x. 
400 ENGLYST, H. N., M. E. QUIGLEY, AND G. J. HUDSON. 1994. "Determination of Dietary 401 Fibre as Non-Starch Polysaccharides with Gas-Liquid Chromatographic, High402 Performance Liquid Chromatographic or Spectrophotometric Measurement of Constituent 403 Sugars." Analyst 119 (7): 1497-1509. doi:10.1039/AN9941901497.

404 ENGLYST, K. N., G. J. HUDSON, AND H. N. ENGLYST., eds. 2000. Starch Analysis in 405 Food: Wiley Online Library. doi:10.1002/9780470027318.a1029.

406 FARRELL, D. J., R. A. PEREZ-MALDONADO, AND P. F. MANNION. 1999. "Optimum 407 Inclusion of Field Peas, Faba Beans, Chick Peas and Sweet Lupins in Poultry Diets. II. 408 Broiler Experiments." $\quad$ British Poultry Science $40 \quad$ (5): 674-680. 409 doi:10.1080/00071669987070.

410 FINNEY, D. J., ed. 1978. Statistical Method in Biological Assay. 3rd ed. London and High 411 Wycombe: Charles Griffin \& Co. doi:10.1002/bimj.4710210714.

412 FRU-NJI, F., E. NIESS, AND E. PFEFFER. 2007. "Effect of Graded Replacement of 413 Soybean Meal by Faba Beans (Vicia Faba L.) or Field Peas (Pisum Sativum L.) in Rations 414 for Laying Hens on Egg Production and Quality." The Journal of Poultry Science 44 (1): 34 415 41. doi:10.2141/jpsa.44.34.

416 GASPARRI, N. I., H. R. GRAU, AND J. G. ANGONESE. 2013. "Linkages Between Soybean 417 and Neotropical Deforestation: Coupling and Transient Decoupling Dynamics in A Multi418 Decadal Analysis." Global Environmental Change 23 (6): 1605-1614. 419 doi:10.1016/j.gloenvcha.2013.09.007.

420 HELSPER, J. P., J. M. HOOGENDIJK, A. VAN NOREL, AND K. BURGER-MEYER. 1993. 421 "Antinutritional Factors in Faba Beans (Vica Faba L.) as Affected by Breeding Toward the 422 Absence of Condensed Tannins." Journal of Agricultural and Food Chemistry 41 (7): 1058423 1061. doi:10.1021/jf00031a008. 
424 IGBASAN, F. A., W. GUENTER, AND B. A. SLOMINSKI. 1997. "Field Peas: Chemical 425 Composition and Energy and Amino Acid Availabilities for Poultry." Canadian Journal of 426 Animal Science 77 (2): 293-300. doi:10.4141/a96-103.

KWANYUEN, P., AND J. W. BURTON. 2005. "A Simple and Rapid Procedure for Phytate 428 Determination in Soybeans and Soy Products." Journal of the American Oil Chemists' 429 Society 82 (2): 81-85. doi:10.1007/s11746-005-1046-9.

LACASSAGNE, L., J. P. MELCION, F. DE MONREDON, AND B. CARRÉ. 1991. "The 431 Nutritional Values of Faba Bean Flours Varying in Their Mean Particle Size in Young 432 Chickens." Animal Feed Science and Technology 34 (1-2): 11-19. doi:10.1016/03778401(94)90187-2.

LACASSAGNE, L., M. FRANCESCH, B. CARRÉ, AND J. P. MELCION. 1988. "Utilization of Tannin-containing and Tannin-Free Faba Beans (Vicia Faba) by Young Chicks: Effects of Pelleting Feeds on Energy, Protein and Starch Digestibility." Animal Feed Science and Technology 20 (1): 59-68. doi:10.1016/0377-8401(88)90127-7.

MAKKAR, H. P., M. BLÜMMEL, N. K. BOROWY, AND K. BECKER. 1993. "Gravimetric Determination of Tannins and Their Correlations with Chemical and Protein Precipitation Methods." Journal of the Science of Food and Agriculture 61 (2): 161-165. doi:10.1002/jsfa.2740610205.

MARQUARDT, R. R., AND A. T. WARD. 1979. "Chick Performance as Affected by 443 Autoclave Treatment of Tannin-Containing and Tannin-Free Cultivars of Faba Beans." 444 Canadian Journal of Animal Science 59 (4): 781-789. doi:10.4141/cjas79-099.

METAYER, J. P., B. BARRIER-GUILLOT, F. SKIBA, K. CREPON, I. BOUVAREL, P. 446 MARGET, G. DUC, AND M. LESSIRE. 2003. "Nutritional Value of Three Faba Bean 447 Cultivars for Broiler Chickens and Adult Cockerels." British Poultry Science 44 (5): 814 $448 \quad 815$. doi:10.1080/00071660410001666970. 
449 NALLE, C. L., G. RAVINDRAN, AND V. RAVINDRAN. 2010b. "Influence of Dehulling on

450 the Apparent Metabolisable Energy and Ileal Amino Acid Digestibility of Grain Legumes for 451 Broilers." Journal of the Science of Food and Agriculture 90 (7): 1227-1231. 452 doi:10.1002/jsfa.3953.

453 NALLE, C. L., V. RAVINDRAN, AND G. RAVINDRAN. 2010a. "Nutritional Value of Faba 454 Beans (Vicia Faba L.) for Broilers: Apparent Metabolisable Energy, Ileal Amino Acid 455 Digestibility and Production Performance." Animal Feed Science and Technology 156 (3456 4): 104-111. doi:10.1016/j.anifeedsci.2010.01.010.

457 O'NEILL, H. V. M., M. RADEMACHER, I. MUELLER-HARVEY, E. STRINGANO, S. 458 KIGHTLEY, AND J. WISEMAN. 2012. "Standardised lleal Digestibility of Crude Protein and 459 Amino Acids of UK-Grown Peas and Faba Beans by Broilers." Animal Feed Science and 460 Technology 175 (3-4): 158-167. doi:10.1016/j.anifeedsci.2012.05.004.

461 OOMAH, B. D., G. LUC, C. LEPRELLE, J. C. DROVER, J. E. HARRISON, AND M. OLSON. 462 2011. "Phenolics, Phytic Acid, and Phytase in Canadian-Grown Low-Tannin Faba Bean 463 (Vicia Faba L.) Genotypes." Journal of Agricultural and Food Chemistry 59 (8): 3763-3771. 464 doi:10.1021/jf200338b.

465 ORTIZ, L. T., C. CENTENO, AND J. TREVINO. 1993. "Tannins in Faba Bean Seeds: Effects 466 on the Digestion of Protein and Amino Acids in Growing Chicks." Animal Feed Science and 467 Technology 41 (4): 271-278. doi:10.1016/0377-8401(93)90002-2.

468 PGRO (PROCESSORS AND GROWERS RESEARCH ORGANISATION). 2017. Pulse 469 Agronomy Guide. [Online]. PGRO. Available from: https://www.pgro.org/downloads/PGRO470 AGRONOMY-GUIDE-2017.pdf [Accessed 20 March 2020].

471 PIRGOZLIEV, V. R., C. L. BIRCH, S. P. ROSE, P. S. KETTLEWELL, AND M. R. BEDFORD. 472 2003. "Chemical Composition and the Nutritive Quality of Different Wheat Cultivars for 473 Broiler Chickens." British Poultry Science 44 (3): 464-475. doi:10.1080/ 4740007166031000085594. 
475 PIRGOZLIEV, V., AND M. R. BEDFORD. 2013. "Energy Utilisation and Growth 476 Performance of Chicken Fed Diets Containing Graded Levels of Supplementary Bacterial 477 Phytase." British Journal of Nutrition 109 (2): 248-253. doi:10.1017/S0007114512000943.

478 PIRGOZLIEV, V., F. KARAdAS, S. P. ROSE, A. BECCACCIA, M. W. MIRZA, AND A. M. 479 AMERAH. 2015a. "Dietary Xylanase Increases Hepatic Vitamin E Concentration of 480 Chickens Fed Wheat Based Diet." Journal of Animal and Feed Sciences 24 (1): 80-84. 481 doi:10.22358/jafs/65656/2015.

482

483

PIRGOZLIEV, V., I. WHITING, J. WILSON, S. P. ROSE, M. W. MIRZA, S. IVANOVA, AND D. KANEV. 2015b. "Nutrient Availability of Wheat Distillers Dried Grains with Solubles (DDGS) for Broilers." Zivotnovudni Nauki 4: 17-24.

PIRGOZLIEV, V., M. W. MIRZA, AND S. P. ROSE. 2015c. "Hard Wheat Instead of Soft Wheat in Pelleted Diets Results in Improved Feed Efficiency in Broiler Chickens." British Poultry Abstracts 11 (1).

PIRGOZLIEV, V., T. ACAMOVIC, AND M. R. BEDFORD. 2009. "Previous Exposure to Dietary Phytase Reduces the Endogenous Energy Losses from Precision-Fed Chickens." British Poultry Science 50 (5): 598-605. doi: 10.1080/00071660903255268.

RUBIO, L. A., G. GRANT, S. BARDOCZ, P. DEWEY, AND A. PUSZTAI. 1992. "Mineral Excretion of Rats Fed on Diets Containing Faba Beans (Vicia Faba L.) or Faba Bean Fractions." British Journal of Nutrition 67 (2): 295-302. doi:10.1079/bjn19920033.

SMITH, C., W. VAN MEGEN, L. TWAALFHOVEN, AND C. HITCHCOCK. 1980. "The Determination of Trypsin Inhibitor Levels in Foodstuffs." Journal of the Science of Food and Agriculture 31 (4): 341-350. doi:10.1002/jsfa.2740310403.

STATISTA. 2020. Volume of Soybeans Imported into the United Kingdom (UK) From Season 2002/03 to 2017/18 (in tonnes). [Online]. Available from: https://www.statista.com/statistics/299719/soybean-uk-imports-from-eu-countries-unitedkingdom/ [Accessed 20 March 2020]. 
501 TANNER, S. D., V. I. BARANOV, AND D. R. BANDURA. 2002. "Reaction Cells and Collision 502 Cells for ICP-MS: A Tutorial Review." Spectrochimica Acta Part B: Atomic Spectroscopy 57 503 (9): 1361-1452. doi:10.1016/s0584-8547(02)00069-1.

504 USAYRAN, N. N., H. SHA'AR, G. W. BARBOUR, S. K. YAU, F. MAALOUF, AND M. T. 505 FARRAN. 2014. "Nutritional Value, Performance, Carcass Quality, Visceral Organ Size, 506 and Blood Clinical Chemistry of Broiler Chicks Fed 30\% Tannin-Free Fava Bean Diets." 507 Poultry Science 93 (8): 2018-2027.

508 VICENTI, A., F. TOTEDA, L. DI TURI, C. COCCA, M. PERRUCCI, L. MELODIA, AND M. 509 RAGNI. 2009. "Use of Sweet Lupin (Lupinus Albus L. Var. Multitalia) in Feeding for Podolian 510 Young Bulls and Influence on Productive Performances and Meat Quality Traits." Meat 511 Science 82 (2): 247-251. doi:10.1016/j.meatsci.2009.01.018.

512 VILARIÑO, M., J. P. MÉTAYER, K. CRÉPON, AND G. DUC. 2009. "Effects of Varying 513 Vicine, Convicine and Tannin Contents of Faba Bean Seeds (Vicia Faba L.) on Nutritional 514 Values for Broiler Chicken." Animal Feed Science and Technology 150 (1-2): 114-121. 515 doi:10.1016/j.anifeedsci.2008.08.001.

516 WOYENGO, T. A., AND C. M. NYACHOTI. 2012. "lleal Digestibility of Amino Acids for Zero517 Tannin Faba Bean (Vicia Faba L.) Fed to Broiler Chicks." Poultry Science 91 (2): 439-443. 518 doi:10.3382/ps.2011-01678. 
521 Table 1. Ingredient composition ( $\mathrm{g} / \mathrm{kg}$, as-fed basis) of the experimental broiler chicken

522 balancer formulation.

523

\begin{tabular}{lc}
\hline Ingredient & $\begin{array}{c}\text { Balancer feed } \\
(\mathrm{g} / \mathrm{kg})\end{array}$ \\
\hline Wheat & 533.2 \\
SBM (CP=48\%) & 150 \\
Full fat Soy meal & 175 \\
Maize gluten meal & 37.4 \\
Soy oil & 50 \\
Lysine & 1.9 \\
Methionine & 6.3 \\
Threonine & 1.9 \\
Monocalcium phosphate & 20 \\
Limestone & 15.5 \\
Sodium chloride & 3.8 \\
Vitamin $/ \mathrm{mineral} \mathrm{premix}{ }^{*}$ & 5 \\
& 1000 \\
Determined composition & \\
ME $(\mathrm{MJ} / \mathrm{kg})$ & 13.71 \\
Protein $(\mathrm{g} / \mathrm{kg})$ & 231 \\
Lysine $(\mathrm{g} / \mathrm{kg})$ & 12.4 \\
Met + Cys $(\mathrm{g} / \mathrm{kg})$ & 11.1 \\
Calcium $(\mathrm{g} / \mathrm{kg})$ & 11.1 \\
Phosphorus available $(\mathrm{g} / \mathrm{kg})$ & 8.5 \\
Sodium $(\mathrm{g} / \mathrm{kg})$ & 2.0 \\
\hline
\end{tabular}

\section{5}

$\mathrm{ME}=$ metabolisable energy .

This balancer was fed as a part of complete diet comprised $200 \mathrm{~g} / \mathrm{kg}$ of each experimental field bean sample and $800 \mathrm{~g} / \mathrm{kg}$ of the balancer. Each experimental diet met the diet specification for this strain of broiler chicken (Aviagen Ltd, Edinburgh, UK).

*The vitamin and mineral premix contained vitamins and trace elements to meet breeder's recommendation (Aviagen Ltd., Edinburgh, UK). The premix provided (units/kg diet) retinol, $3600 \mu \mathrm{g}$; cholecalciferol, $125 \mu \mathrm{g} ; \mu$ tocopherol, $34 \mathrm{mg}$; menadione, $3 \mathrm{mg}$; thiamin, $2 \mathrm{mg}$; riboflavin, $7 \mathrm{mg}$; pyridoxine, $5 \mathrm{mg}$; cobalamin, $15 \mu \mathrm{g}$; nicotinic acid, $50 \mathrm{mg}$; pantothenic acid, $15 \mathrm{mg}$; folic acid, $1 \mathrm{mg}$; biotin, $200 \mu \mathrm{g}$; iron, $80 \mathrm{mg}$; copper, $10 \mathrm{mg}$; manganese, $100 \mathrm{mg}$; cobalt, $0.5 \mathrm{mg}$; zinc, $80 \mathrm{mg}$; iodine, $1 \mathrm{mg}$; selenium, $0.2 \mathrm{mg}$; and molybdenum, $0.5 \mathrm{mg}$. 
542 Table 2. The chemical composition (dry matter basis) of ten UK grown studied field bean 543 cultivars.

\begin{tabular}{lccccc}
\hline Bean cultivar & $\begin{array}{c}\text { Dry matter } \\
(\mathrm{g} / \mathrm{kg})\end{array}$ & $\begin{array}{c}\text { Ash } \\
(\mathrm{g} / \mathrm{kg})\end{array}$ & $\begin{array}{c}\text { Ether } \\
\text { extract } \\
(\mathrm{g} / \mathrm{kg})\end{array}$ & $\begin{array}{c}\text { Crude } \\
\text { protein } \\
(\mathrm{g} / \mathrm{kg})\end{array}$ & $\begin{array}{c}\text { Gross energy } \\
(\mathrm{MJ} / \mathrm{kg})\end{array}$ \\
\hline Arthur & 859 & 32.0 & 11.6 & 270.6 & 18.41 \\
Buzz & 845 & 38.2 & 10.7 & 276.0 & 18.27 \\
Clipper & 854 & 35.6 & 9.4 & 284.8 & 18.38 \\
Divine & 866 & 38.6 & 9.2 & 299.6 & 18.60 \\
Fuego & 855 & 34.3 & 12.9 & 269.8 & 18.58 \\
Fury & 856 & 33.8 & 10.5 & 281.0 & 18.56 \\
Honey & 836 & 34.7 & 10.8 & 293.8 & 18.56 \\
Maris Bead & 858 & 33.5 & 10.5 & 304.5 & 18.41 \\
Sultan & 856 & 39.4 & 11.7 & 244.6 & 18.27 \\
Wizard & 855 & 38.8 & 10.5 & 299.7 & 18.59 \\
CV\% & 1.0 & 7.4 & 10.1 & 6.5 & 0.7 \\
\hline
\end{tabular}

544 
Table 3. Carbohydrate composition ( $\mathrm{g} / \mathrm{kg} \mathrm{DM}$ ) of ten UK grown studied field bean cultivars.

\begin{tabular}{|c|c|c|c|c|c|c|c|c|c|c|c|}
\hline \multirow{2}{*}{ Bean cultivar } & \multirow{2}{*}{ Fraction } & \multicolumn{8}{|c|}{ NSP constituent sugars } & \multirow{2}{*}{ Total NSPs } & \multirow{2}{*}{ Total starch } \\
\hline & & Rha & Fuc & Ara & $X y l$ & Man & Gal & Glu & $\overline{\text { GalA }}$ & & \\
\hline & Soluble sugar & 1.0 & 0.7 & 10.2 & 4.6 & 2.6 & 5.3 & 11.6 & 14.3 & 50.3 & \\
\hline \multirow{3}{*}{ Arthur } & Insoluble sugar & 0.0 & 0.2 & 13.4 & 10.4 & 2.8 & 2.8 & 60.7 & 8.0 & 98.3 & 488 \\
\hline & Total sugar & 1.0 & 0.9 & 23.5 & 15.0 & 5.4 & 8.1 & 72.4 & 22.3 & 148.6 & \\
\hline & Soluble sugar & 0.6 & 0.4 & 12.0 & 5.3 & 2.2 & 5.0 & 10.6 & 14.5 & 50.6 & \\
\hline \multirow[t]{3}{*}{ Buzz } & Insoluble sugar & 0.4 & 0.6 & 12.5 & 14.4 & 4.1 & 3.4 & 91.9 & 11.9 & 139.2 & 452 \\
\hline & Total sugar & 1.0 & 1.0 & 24.5 & 19.8 & 6.2 & 8.4 & 102.5 & 26.4 & 189.7 & \\
\hline & Soluble sugar & 1.3 & 0.7 & 10.4 & 5.8 & 2.6 & 6.8 & 25.0 & 20.3 & 72.8 & \\
\hline \multirow[t]{3}{*}{ Clipper } & Insoluble sugar & 0.0 & 0.5 & 13.1 & 14.6 & 5.9 & 3.9 & 125.7 & 14.1 & 177.6 & 397 \\
\hline & Total sugar & 1.3 & 1.2 & 23.4 & 20.3 & 8.5 & 10.6 & 150.7 & 34.3 & 250.4 & \\
\hline & Soluble sugar & 1.1 & 0.9 & 9.6 & 5.2 & 2.5 & 5.8 & 8.5 & 12.9 & 46.4 & \\
\hline \multirow{3}{*}{ Divine } & Insoluble sugar & 0.0 & 0.0 & 11.7 & 15.0 & 3.4 & 3.9 & 89.2 & 10.8 & 134.0 & 434 \\
\hline & Total sugar & 1.1 & 0.9 & 21.3 & 20.2 & 5.9 & 9.7 & 103.6 & 23.6 & 180.4 & \\
\hline & Soluble sugar & 1.0 & 0.5 & 9.7 & 5.5 & 2.2 & 5.0 & 15.8 & 14.4 & 54.1 & \\
\hline \multirow[t]{3}{*}{ Fuego } & Insoluble sugar & 0.0 & 0.5 & 13.1 & 12.1 & 4.1 & 3.8 & 73.2 & 10.1 & 116.9 & 473 \\
\hline & Total sugar & 1.0 & 1.0 & 22.9 & 17.5 & 6.3 & 8.8 & 89.0 & 24.4 & 171.0 & \\
\hline & Soluble sugar & 1.1 & 0.8 & 9.7 & 5.4 & 2.1 & 4.8 & 5.8 & 14.5 & 44.1 & \\
\hline \multirow[t]{3}{*}{ Fury } & Insoluble sugar & 0.0 & 0.2 & 12.1 & 15.5 & 4.2 & 3.5 & 91.4 & 9.4 & 136.4 & 464 \\
\hline & Total sugar & 1.1 & 1.0 & 21.8 & 20.9 & 6.3 & 8.4 & 97.2 & 23.9 & 180.5 & \\
\hline & Soluble sugar & 1.1 & 0.7 & 17.6 & 5.6 & 6.9 & 6.9 & 7.2 & 16.9 & 62.9 & \\
\hline \multirow[t]{3}{*}{ Honey } & Insoluble sugar & 0.0 & 0.3 & 11.1 & 10.0 & 2.1 & 2.6 & 62.8 & 7.1 & 95.9 & 517 \\
\hline & Total sugar & 1.1 & 1.0 & 28.7 & 15.6 & 8.9 & 9.5 & 70.1 & 23.9 & 158.8 & \\
\hline & Soluble sugar & 0.9 & 0.7 & 7.6 & 2.8 & 1.4 & 4.9 & 1.5 & 10.1 & 30.0 & \\
\hline \multirow[t]{3}{*}{ Maris Bead } & Insoluble sugar & 0.2 & 0.2 & 12.5 & 11.4 & 4.2 & 3.3 & 80.9 & 12.7 & 125.5 & 443 \\
\hline & Total sugar & 1.1 & 0.9 & 20.1 & 14.3 & 5.6 & 8.2 & 82.3 & 22.8 & 155.5 & \\
\hline & Soluble sugar & 1.0 & 0.4 & 9.7 & 3.7 & 2.1 & 5.4 & 15.4 & 17.1 & 54.8 & \\
\hline \multirow[t]{3}{*}{ Sultan } & Insoluble sugar & 0.0 & 0.5 & 11.4 & 8.2 & 4.6 & 3.1 & 96.1 & 11.6 & 135.4 & 467 \\
\hline & Total sugar & 1.0 & 0.9 & 21.0 & 11.9 & 6.6 & 8.5 & 111.5 & 28.7 & 190.2 & \\
\hline & Soluble sugar & 0.8 & 0.5 & 11.1 & 3.6 & 2.0 & 5.6 & 4.9 & 14.2 & 42.8 & \\
\hline \multirow[t]{3}{*}{ Wizard } & Insoluble sugar & 0.3 & 0.4 & 11.8 & 15.8 & 5.0 & 3.2 & 101.8 & 12.1 & 150.4 & 424 \\
\hline & Total sugar & 1.2 & 0.9 & 23.0 & 19.5 & 6.9 & 8.8 & 106.7 & 26.3 & 193.2 & \\
\hline & Soluble sugar & 19.4 & 27.0 & 24.8 & 21.3 & 57.7 & 13.4 & 63.8 & 18.2 & 22.9 & \\
\hline \multirow[t]{2}{*}{ CV\% } & Insoluble sugar & 171.4 & 55.3 & 6.4 & 21.0 & 27.0 & 12.9 & 22.1 & 20.0 & 18.4 & 7.4 \\
\hline & Total sugar & 9.4 & 10.5 & 10.4 & 17.8 & 17.4 & 9.1 & 23.5 & 14.0 & 15.8 & \\
\hline
\end{tabular}

Rha, rhamnose; Fuc, fucose; Ara, arabinose; Xyl, xylose; Man, mannose; Gal, galactose; Glu, glucose; GalA, galacturonic acid; Total-NSPs, total non-starch polysaccharides; Each value represents mean of duplicate analysis. 
Table 4. Mineral composition (dry matter basis) of ten UK grown studied field bean cultivars.

\begin{tabular}{|c|c|c|c|c|c|c|c|c|c|c|c|}
\hline \multirow[b]{2}{*}{$\begin{array}{l}\text { Beans } \\
\text { cultivar }\end{array}$} & \multicolumn{11}{|c|}{ Mineral } \\
\hline & $\begin{array}{l}\text { Calcium } \\
(\mathrm{g} / \mathrm{kg})\end{array}$ & $\begin{array}{l}\text { Magnesium } \\
(\mathrm{g} / \mathrm{kg})\end{array}$ & $\begin{array}{c}\text { Phosphorus } \\
(\mathrm{g} / \mathrm{kg})\end{array}$ & $\begin{array}{c}\text { Potassium } \\
(\mathrm{g} / \mathrm{kg})\end{array}$ & $\begin{array}{l}\text { Sodium } \\
(\mathrm{g} / \mathrm{kg})\end{array}$ & $\begin{array}{l}\text { Sulphur } \\
(\mathrm{g} / \mathrm{kg})\end{array}$ & $\begin{array}{l}\text { Boron } \\
(\mathrm{mg} / \mathrm{kg})\end{array}$ & $\begin{array}{l}\text { Copper } \\
\text { (mg/kg) }\end{array}$ & $\begin{array}{c}\text { Iron } \\
(\mathrm{mg} / \mathrm{kg})\end{array}$ & $\begin{array}{l}\text { Manganese } \\
(\mathrm{mg} / \mathrm{kg})\end{array}$ & $\begin{array}{c}\text { Zinc } \\
(\mathrm{mg} / \mathrm{kg})\end{array}$ \\
\hline Arthur & 1.35 & 1.17 & 4.33 & 11.15 & 0.19 & 1.89 & 11.25 & 8.24 & 72.95 & 23.80 & 39.45 \\
\hline Clipper & 1.60 & 1.47 & 6.05 & 11.10 & 0.43 & 1.92 & 10.55 & 18.60 & 83.60 & 19.55 & 52.05 \\
\hline Divine & 1.18 & 1.43 & 5.05 & 13.70 & $<0.12$ & 2.92 & 10.60 & 12.80 & 62.30 & 13.85 & 45.90 \\
\hline Fuego & 1.07 & 1.34 & 4.96 & 11.85 & 0.30 & 2.12 & 11.50 & 13.90 & 65.05 & 11.10 & 48.65 \\
\hline Maris Bead & 1.00 & 1.27 & 5.33 & 11.20 & $<0.12$ & 2.08 & 12.15 & 16.00 & 51.40 & 12.30 & 53.20 \\
\hline Sultan & 1.19 & 1.42 & 4.61 & 13.10 & $<0.12$ & 1.47 & 10.65 & 9.54 & 67.55 & 23.60 & 64.30 \\
\hline Wizard & 1.41 & 1.46 & 6.87 & 12.05 & $<0.12$ & 2.22 & 10.70 & 15.95 & 68.50 & 15.20 & 43.85 \\
\hline CV\% & 19.60 & 8.3 & 15.5 & 7.3 & $N^{*}$ & 19.4 & 5.1 & 26.3 & 16.1 & 40.4 & 14.1 \\
\hline
\end{tabular}

*NA, not applicable; Each value represents mean of duplicate analysis. 
Table 5. Total phenols, tannins, non-tannin phenols (NTPH), condensed tannins, phytate and trypsin inhibitor contents (mg/g DM) of ten UK grown studied field bean cultivars.

\begin{tabular}{lcccccc}
\hline Bean cultivar & $\begin{array}{c}\text { Total } \\
\text { phenols }^{\mathrm{a}}\end{array}$ & Tannins $^{\mathrm{a}}$ & NTPH $^{\mathrm{a}}$ & $\begin{array}{c}\text { Condensed } \\
\text { tannins }\end{array}$ & Phytate & $\begin{array}{c}\text { Trypsin } \\
\text { inhibitors }\end{array}$ \\
\hline Arthur & 4.5 & 3.5 & 1.0 & 2.8 & 9.86 & 3.1 \\
Buzz & 4.7 & 2.2 & 2.5 & 2.9 & 20.84 & 2.6 \\
Clipper & 7.1 & 4.6 & 2.5 & 5.3 & 16.62 & 3.3 \\
Divine & 7.1 & 4.8 & 2.4 & 6.2 & 13.35 & 4.2 \\
Fuego & 8.3 & 6.1 & 2.3 & 6.8 & 12.90 & 4.4 \\
Fury & 6.3 & 4.3 & 2.0 & 4.7 & 13.77 & 3.7 \\
Honey & 7.3 & 4.4 & 2.8 & 3.9 & 13.51 & 3.4 \\
Maris Bead & 6.9 & 6.1 & 0.8 & 4.5 & 13.90 & 3.8 \\
Sultan & 10.9 & 8.3 & 2.6 & 7.3 & 10.63 & 2.3 \\
Wizard & 8.1 & 6.8 & 1.4 & 6 & 19.80 & 3.8 \\
CV\% & 25.7 & 34.3 & 35.0 & 30.9 & 24.6 & 19.2 \\
\hline
\end{tabular}

${ }^{a}$ As tannic acid equivalents; ${ }^{b}$ As leukocyanidin equivalents. Each value represents mean of triplicate analysis. 
Table 6. Weight of 1000 grains (TGW), water holding capacity (WHC), water extract viscosity (WEV), cotyledon and seed-coat ratio and colour score $\left(\mathrm{L}^{*}, \mathrm{a}^{*}\right.$ and $\left.\mathrm{b}^{*}\right)$ of flour of ten UK grown field bean cultivars*.

\begin{tabular}{lcccccccc}
\hline $\begin{array}{l}\text { Bean } \\
\text { cultivar }\end{array}$ & $\begin{array}{c}\text { TGW } \\
(\mathrm{g} \mathrm{DM})\end{array}$ & $\begin{array}{c}\text { WHC } \\
(\mathrm{g} / \mathrm{kg})\end{array}$ & $\begin{array}{c}\text { WEV } \\
(\mathrm{cP})\end{array}$ & $\begin{array}{c}\text { Cotyledon } \\
(\mathrm{g} / \mathrm{kg})\end{array}$ & $\begin{array}{c}\text { Seed- } \\
\text { coat } \\
(\mathrm{g} / \mathrm{kg})\end{array}$ & $\mathrm{L}^{*}$ & $\mathrm{a}^{*}$ & $\mathrm{~b}^{*}$ \\
\hline Arthur & 685 & 915 & 2.07 & 866.4 & 133.6 & 93.59 & 1.07 & 17.72 \\
Buzz & 693 & 871 & 2.41 & 868.9 & 131.1 & 91.49 & 1.27 & 14.69 \\
Clipper & 539 & 943 & 4.52 & 843.4 & 156.6 & 91.76 & 1.17 & 18.94 \\
Divine & 444 & 935 & 4.18 & 863.2 & 136.8 & 94.66 & 0.99 & 17.59 \\
Fuego & 466 & 1005 & 3.58 & 858.1 & 141.9 & 94.25 & 1.14 & 17.96 \\
Fury & 483 & 1010 & 4.59 & 863.7 & 136.3 & 95.16 & 1.21 & 18.22 \\
Honey & 754 & 956 & 4.81 & 889.8 & 110.2 & 94.63 & 1.06 & 17.04 \\
Maris Bead & 311 & 961 & 5.01 & 876.7 & 123.3 & 93.18 & 1.01 & 19.05 \\
Sultan & 407 & 997 & 4.04 & 844.5 & 155.5 & 87.71 & 1.44 & 22.29 \\
Wizard & 681 & 947 & 3.40 & 867.3 & 132.7 & 94.04 & 1.18 & 19.34 \\
CV\% & 27.1 & 4.5 & 25.8 & 1.6 & 10.1 & 2.4 & 11.7 & 10.6 \\
\hline
\end{tabular}

Each value of WHC and WEV represents mean of triplicate analysis.

* $L^{*}$, lightness-darkness degree of bean flour; $a^{*}$, redness-greenness degree of bean flour; $b^{*}$, yellownessblueness degree of bean flour; Each value represents mean of triplicate analysis. 
Table 7. Linearity table.

\begin{tabular}{lrrrrrrrr}
\hline Variable & \multicolumn{3}{c}{ Bean rate in the diets } & SEM & \multicolumn{3}{c}{$P$ value } \\
\cline { 2 - 3 } \cline { 8 - 9 } & $0.0 \%$ & $10.0 \%$ & $20.0 \%$ & & & Treatment & Linear & Quadratic \\
\hline Total collection & & & & & & & \\
AMEn (MJ/kg_DM) & 14.27 & 13.86 & 13.30 & 0.096 & $<0.001$ & $<0.001$ & 0.540 \\
NR & 0.625 & 0.623 & 0.621 & 0.0033 & 0.697 & 0.404 & 0.998 \\
FR & 0.749 & 0.756 & 0.771 & 0.0110 & 0.400 & 0.193 & 0.779 \\
DMR & 0.716 & 0.702 & 0.683 & 0.0048 & $<0.001$ & $<0.001$ & 0.644 \\
\hline
\end{tabular}

$\mathrm{SEM}=$ pooled standard errors of mean; $\mathrm{AMEn}=\mathrm{N}$-corrected apparent metabolisable energy; $\mathrm{NR}=$ nitrogen retention coefficient; $F R=$ fat retention coefficient; $D M R=$ dry matter retention coefficient. 
Table 8. Daily feed intake (FI), weight gain (WG) and feed conversion ratio (FCR) of broiler chickens fed on diets containing $200 \mathrm{~g} / \mathrm{kg}$ of one of the ten different UK grown field bean cultivar samples. Nitrogen-corrected apparent metabolisable energy (AMEn), total tract fat (FR) retention, nitrogen (NR) and dry matter (DMR) retention coefficients (obtained with slope ratio method) of ten UK grown field bean cultivar samples fed to broiler chickens.

\begin{tabular}{lcccccccc}
\hline Diet & $\begin{array}{c}\mathrm{FI} \\
(\mathrm{g} \mathrm{DM} / \mathrm{b} / \mathrm{d})\end{array}$ & $\begin{array}{c}\text { WG } \\
(\mathrm{g} / \mathrm{b} / \mathrm{d})\end{array}$ & $\begin{array}{c}\text { FCR } \\
(\mathrm{g}: \mathrm{g})\end{array}$ & $\begin{array}{c}\text { AMEn bean } \\
(\mathrm{MJ} / \mathrm{kg} \mathrm{DM})\end{array}$ & $\begin{array}{c}\text { AMEn diet } \\
(\mathrm{MJ} / \mathrm{kg} \mathrm{DM})\end{array}$ & NR & FR & DMR \\
\hline Arthur & 57.4 & 46.2 & $1.244^{\mathrm{abc}}$ & $9.19^{\mathrm{abc}}$ & $13.25^{\mathrm{abc}}$ & 0.596 & 0.752 & $0.546^{\mathrm{ab}}$ \\
Buzz & 59.3 & 47.3 & $1.254^{\mathrm{bc}}$ & $8.20^{\mathrm{ab}}$ & $13.06^{\mathrm{ab}}$ & 0.556 & 0.740 & $0.491^{\mathrm{ab}}$ \\
Clipper & 58.4 & 47.1 & $1.240^{\mathrm{abc}}$ & $9.16^{\mathrm{abc}}$ & $13.25^{\mathrm{abc}}$ & 0.594 & 0.903 & $0.528^{\mathrm{ab}}$ \\
Divine & 60.0 & 50.0 & $1.201^{\mathrm{a}}$ & $9.96^{\mathrm{c}}$ & $13.41^{\mathrm{c}}$ & 0.624 & 0.916 & $0.571^{\mathrm{b}}$ \\
Fuego & 57.7 & 46.9 & $1.233^{\mathrm{abc}}$ & $9.78^{\mathrm{bc}}$ & $13.37^{\mathrm{bc}}$ & 0.606 & 0.861 & $0.562^{\mathrm{b}}$ \\
Fury & 58.5 & 48.2 & $1.212^{\mathrm{ab}}$ & $9.84^{\mathrm{bc}}$ & $13.38^{\mathrm{bc}}$ & 0.572 & 0.868 & $0.566^{\mathrm{b}}$ \\
Honey & 58.8 & 48.3 & $1.220^{\mathrm{ab}}$ & $9.43^{\mathrm{abc}}$ & $13.30^{\mathrm{abc}}$ & 0.604 & 0.858 & $0.550^{\mathrm{b}}$ \\
Maris Bead & 59.5 & 48.7 & $1.221^{\mathrm{ab}}$ & $9.35^{\mathrm{abc}}$ & $13.29^{\mathrm{abc}}$ & 0.558 & 0.855 & $0.554^{\mathrm{b}}$ \\
Sultan & 57.4 & 45.1 & $1.274^{\mathrm{c}}$ & $7.78^{\mathrm{a}}$ & $12.97^{\mathrm{a}}$ & 0.538 & 0.850 & $0.461^{\mathrm{a}}$ \\
Wizard & 56.5 & 46.4 & $1.217^{\mathrm{ab}}$ & $9.52^{\mathrm{bc}}$ & $13.32^{\mathrm{bc}}$ & 0.556 & 0.879 & $0.547^{\mathrm{ab}}$ \\
Mean & 58.3 & 47.4 & 1.232 & 9.22 & 13.26 & 0.580 & 0.848 & 0.538 \\
CV\% & 5.3 & 6.0 & 2.5 & 11.3 & 10.2 & 10.3 & 13.8 & 9.8 \\
SEM & 1.10 & 1.01 & 0.0110 & 0.370 & 0.074 & 0.0211 & 0.0415 & 0.0186 \\
$P$ value & 0.455 & 0.060 & $<0.001$ & $<0.001$ & $<0.001$ & 0.091 & 0.061 & 0.001 \\
\hline
\end{tabular}

Each value represents mean of eight replicate pens of 5 chicks each; Bird performance was determined from 7 to $21 \mathrm{~d}$ age; AMEn and retention coefficients were determined from 17 to $21 \mathrm{~d}$ age; a,b,c Values within a column with different superscripts differ significantly at $P \leq 0.05$. 
Table 9. Selected correlation coefficients between determined AMEn and laboratory analysis of field bean cultivars.

\begin{tabular}{lrcccccccc}
\hline & AMEn & $L$ & $a$ & $b$ & Starch & $C P$ & NSP tot & NSP $n$ & NSP $S$ \\
\hline $\mathrm{L}$ & 0.924 & & & & & & & & \\
$\mathrm{a}$ & -0.762 & -0.768 & & & & & & & \\
$\mathrm{~b}$ & -0.220 & -0.500 & 0.400 & & & & & & \\
Starch & -0.040 & 0.159 & -0.048 & -0.186 & & & & & \\
CP & 0.658 & 0.683 & -0.772 & -0.338 & -0.294 & & & & \\
NSP tot & -0.197 & -0.364 & 0.396 & 0.189 & -0.757 & -0.073 & & & \\
NSP n & -0.138 & -0.314 & 0.354 & 0.238 & -0.916 & 0.080 & 0.918 & & \\
NSP s & -0.202 & -0.250 & 0.246 & -0.028 & 0.026 & -0.345 & 0.571 & 0.197 & \\
Tannins & -0.111 & -0.371 & 0.312 & 0.894 & -0.129 & -0.201 & 0.050 & 0.137 & -0.162 \\
\hline
\end{tabular}

$d f=7 ; P<0.05\left(r^{2} \geq 0.632 ; 0.765 \leq r^{2}\right) ; P<0.001\left(r^{2} \geq 0.765\right)$.

AMEn, nitrogen-corrected apparent metabolisable energy; $L^{*}$, lightness-darkness degree of bean flour; $a^{*}$, redness-greenness degree of bean flour; $b^{*}$, yellowness-blueness degree of bean flour; Starch, (g/kg DM); CP, crude protein in beans ( $\mathrm{g} / \mathrm{kg}$ DM); NSP tot, NSP $\mathrm{n}$ and NSP $\mathrm{s}$, is respectively total, non-soluble and soluble nonstarch polysaccharide contents in beans ( $\mathrm{g} / \mathrm{kg}$ DM); Tannins, as tannic acid equivalents, content in beans $(\mathrm{mg} / \mathrm{g}$ $\mathrm{DM})$. 